\title{
NUMERYCZNA I DOŚWIADCZALNA ANALIZA ZGINANYCH, SKRĘCANYCH I ŚCINANYCH BELEK ŻELBETOWYCH
}

\begin{abstract}
W artykule zaprezentowano badania doświadczalne i analizy numeryczne belek żelbetowych zginanych, skręcanych i ścinanych. Przedmiotem analizy były belki wspornikowe wykonane w skali naturalnej o przekroju poprzecznym $30 \times 30 \mathrm{~cm}$. Zbrojenie w belkach ukształtowano na podstawie dwóch różnych modeli Strut and Tie (ST). Dla belki B1 model ST stanowiła kratownica przestrzenna, w której ściskane krzyżulce betonowe wydzielone rysami ukośnymi nachylone są do osi pręta pod kątem $45^{\circ}$. Pręty pionowe kratownicy to rozciągane zbrojenie w postaci strzemion. Pas górny i dolny kratownicy to odpowiednio zbrojenie rozciągane i ściskane pasy betonowe. W przypadku belki B2 model ST stanowiła również kratownica przestrzenna o ściskanych krzyżulcach betonowych nachylonych do osi pręta pod kątem 26,6 . Badania doświadczalne 6 belek przeprowadzono w hali laboratoryjnej Wydziału Budownictwa Inżynierii Środowiska i Architektury Politechniki Rzeszowskiej. W celu oceny nośności i zmian sztywności belek spowodowanych zginaniem, skręcaniem i ścinaniem analizowano zależności: przemieszczenie pionowe - siła obciążająca oraz sztywność przekroju na skręcanie. Symulacje numeryczne badanych belek wykonano w programie ATENA 3D- Studio. Do nieliniowej analizy belek żelbetowych wykorzystano trzy modele betonu tj. model betonu do analizy nieliniowej zaproponowany w Eurokodzie 2, model betonu o nazwie ,cementitious”, zaproponowany w programie ATENA, bazujący na zaleceniach Model Code oraz zmodyfikowany przez użytkownika model betonu „,cementitious 2". Zaobserwowano dużą zgodność pomiędzy średnim obciążeniem granicznym uzyskanymi w symulacjach numerycznych a wynikami doświadczalnymi i obrazem zarysowania. W wyniku przeprowadzonych badań doświadczalnych i analiz numerycznych zaobserwowano wpływ przyjętego modelu ST na sztywność i nośność belek.
\end{abstract}

Słowa kluczowe: skręcanie, ścinanie, modele ST, belki, żelbet, MES

\section{Wprowadzenie}

Zjawisko skręcania można zaobserwować w wielu elementach żelbetowych, takich jak przestrzenne konstrukcje ramowe, schody, spiralne pochylnie

\footnotetext{
${ }^{1}$ Lidia Buda-Ożóg, Politechnika Rzeszowska, 35-959 Rzeszów, ul. Poznańska 2, +48 177432402 , lida@prz.edu.pl
} 
itp. Pierwsze badania żelbetowych elementów skręcanych przeprowadził Rausch w 1929 roku [1]. Później intensywne badania nad skręcaniem prowadzone były w latach 60 i 70 tych XX wieku. Z tego okresu pochodzą między innymi publikacje Zia [2] z 1974 r, gdzie można znaleźć wiele danych na temat przeprowadzonych w tym czasie badań i uzyskanych wyników. Obszernym kompendium wiedzy na temat skręcania jest również praca Hsu [3] z 1968 roku. W polskiej literaturze informacje na temat tego zagadnienia można znaleźć w pracach T. Godyckiego - Ćwirko [5], T. Ciężaka [4], artykułach [6, 7, 8] czy sprawozdaniu z badań doświadczalnych [9].

Przeprowadzone dotychczas badania i analizy nie pozwalają jednak na pełny opis tego zjawiska w żelbecie, a zaproponowane w EC2 [10] zasady obliczania SGN i SGU wydają się być niekompletne. Powodem tego stanu jest skomplikowany charakter zjawiska i trudności związane z wykonaniem badań doświadczalnych. Elementy poddane skręcaniu znajdują się w przestrzennym stanie napreżeń i odkształceń. Dodatkowo, podlegają jednocześnie działaniu siły poprzecznej i momentu zginającego, a zatem są skręcane i ścinane. Badania skręcanych elementów żelbetowych prowadzone są najczęściej na elementach przestrzennych w skali naturalnej i wymagają specjalnie to tego celu wykonanych stanowisk i urządzeń badawczych.

Innym a zarazem łatwiejszym rozwiązaniem mogą być symulacje numeryczne, których rozwój w procesie analizy i projektowania konstrukcji inżynierskich, nastąpił w ostatnich latach. Ze wszystkich metod numerycznych najczęściej stosowana jest Metoda Elementów Skończonych. Dynamiczny rozwój technik komputerowych pozwala również na wykonywanie analiz nieliniowych dotyczących żelbetowych elementów konstrukcyjnych ze szczególnym uwzględnieniem zróżnicowanych sprężysto-plastycznych charakterystyk materiałowych betonu i stali, rzeczywistego układu zbrojenia, wzajemnej współpracy obu materiałów oraz symulacji mechanizmu zniszczenia elementów. Pomimo to modelowanie elementów żelbetowych zginanych, skręcanych i ścinanych ciągle nie jest dość dobrze rozpoznanym zjawiskiem, a uzyskiwane $\mathrm{z}$ modeli numerycznych wyniki nie zawsze są zgodne z wynikami badań doświadczalnych. Spowodowane to jest występującymi trudnościami $\mathrm{w}$ modelowaniu mechanizmów zniszczenia betonu $\mathrm{w}$ złożonym stanie naprężeń.

Celem niniejszej pracy jest analiza zgodności wyników otrzymanych z symulacji numerycznych belek żelbetowych jednocześnie zginanych, ścinanych i skręcanych, utworzonych $\mathrm{z}$ uwzględnieniem różnych modeli betonu $\mathrm{z}$ wynikami przeprowadzonych badań doświadczalnych. W pracy analizowano belki o zbrojeniu ukształtowanym na podstawie dwóch różnych modeli Strut and Tie (ST). Przedstawione analizy są kontynuacją zagadnień prezentowanych na konferencji w Krynicy w latach 2015 i 2016 [11], rozszerzone są o badania doświadczalne, walidację modeli numerycznych i analizę sztywności na skręcanie. 


\section{Analizowane belki}

Przedmiotem analizy były belki wspornikowe oznaczone symbolem B1 i B2 o kształcie i obciążeniu, przedstawione na rys. 1.

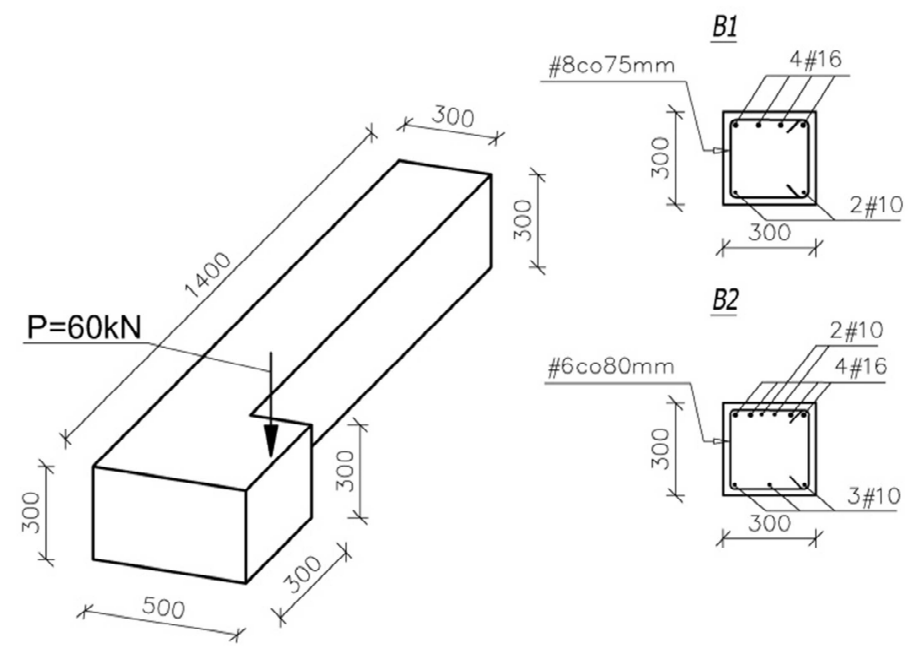

Rys. 1. Analizowane belki wspornikowe

Fig. 1. Analyzed cantilever beams

Przedstawiony sposób zbrojenia belek wynika z przyjętego modelu ST. Dla belki B1 model ST stanowiła kratownica przestrzenna nawiązująca kształtem do kratownicy Leonhardta, w której ściskane krzyżulce betonowe wydzielone rysami ukośnymi są na każdym boku pionowym i poziomym nachylone do osi pręta pod kątem $45^{\circ}$. Pręty pionowe kratownicy to rozciągane zbrojenie w postaci strzemion. Pas górny i pas dolny kratownicy to odpowiednio zbrojenie rozciągane i ściskane pasy betonowe. Analogicznie dla belki B2 model ST stanowiła również kratownica przestrzenna, lecz ściskane krzyżulce betonowe przyjęto nachylone do osi pręta pod kątem $26,6^{\circ}$.

Belki zaprojektowano wstępnie z betonu C35/45. Wytrzymałość na ściskanie oraz moduł sprężystości betonu w wykonanych elementach wyznaczono na podstawie statycznej próby ściskania próbek sześciennych o boku 150mm. Wszystkie belki wykonano z tej samej partii betonu z której pobrano beton do oznaczenia parametrów wytrzymałościowych. Otrzymaną wytrzymałość na ściskanie, moduł sprężystości oraz gęstość objętościowa betonu, zestawiono w tabeli 1.

W celu oceny nośności i zmian sztywności belek B1 i B2 spowodowanej zginaniem, skręcaniem i ścinaniem analizowano zależności: przemieszczenie pionowe - siła oraz sztywność przekroju na skręcanie. Sztywności na skręcanie przekroju zarysowanego wyznaczono z zależność: 
Tabela 1. Wytrzymałość na ściskanie, moduł sprężystości oraz gęstość objętościowa betonu w belkach B1 i B2

Table 1. Compression strength, modulus of elasticity and volumetric mass density of concrete for beams B1 and B2

\begin{tabular}{|l|l|l|l|}
\hline $\begin{array}{l}\text { Właściwości } \\
\text { materiałowe }\end{array}$ & Liczba próbek & Wartość średnia & $\begin{array}{l}\text { Odchylenie } \\
\text { standardowe }\end{array}$ \\
\hline $\mathrm{E}_{\mathrm{cm}}[\mathrm{MPa}]$ & 3 & 34867 & 804 \\
\hline $\mathrm{f}_{\mathrm{c}, \mathrm{cube}}[\mathrm{MPa}]$ & 6 & 64,0 & 3,2 \\
\hline$\rho\left[\mathrm{kg} / \mathrm{m}^{3}\right]$ & 6 & 2463 & 8,5 \\
\hline
\end{tabular}

$$
K=\frac{T}{\varphi}
$$

gdzie: $T$ - moment skręcający,

$\varphi$ - kąt skręcenia przekroju.

\section{Badania doświadczalne}

Program badań obejmował 2 serie belek oznaczone symbolem B1, B2. Dla celów statystycznych każda seria zawierała po 3 belki o takich samych parametrach tj. wytrzymałości betonu i sposobie zbrojenia. Badania doświadczalne belek przeprowadzono w Hali Laboratoryjnej Wydziału Budownictwa, Inżynierii Środowiska i Architektury Politechnik Rzeszowskiej. Przykładową belkę na stanowisku badawczym przedstawiono na rys. 2 .

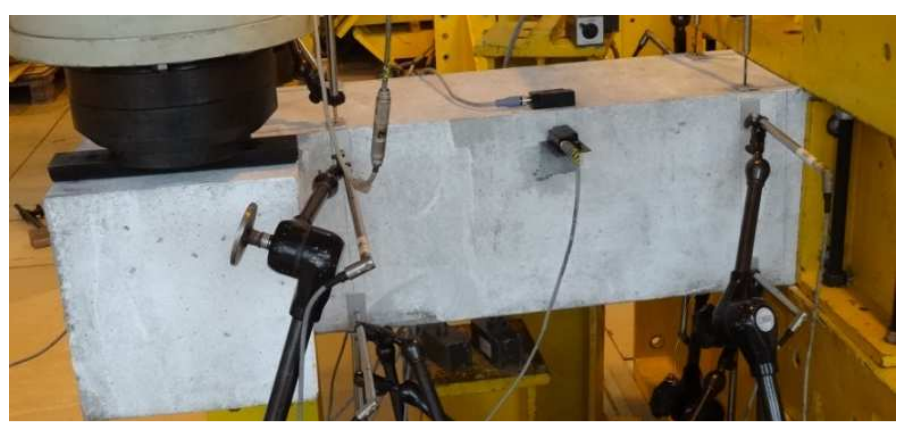

Rys. 2. Belka na stanowisku badawczym

Fig. 2. Beam on the test stand

Podczas całego cyklu obciążania mierzono za pomocą czujników indukcyjnych i tensometrów: kąt skręcenia powierzchni bocznych w kierunku poziomym, kąt skręcenia powierzchni górnej w kierunku pionowym, przemieszczenia poziome i pionowe powierzchni dolnej, górnej i bocznej, naprężenia na powierzchni dolnej i bocznej. Dodatkowo do pomiarów odkształceń powierzchni 
bocznej wykorzystano systemu cyfrowej korelacji obrazu 3D Q-450 firmy Dantec Dynamics z dwiema kamerami cyfrowymi.

Obciążenie w przyjętym programie badawczym narastało skokowo, co $5 \mathrm{kN}$ do $70 \%$ obciążenia niszczącego tj. około $70 \mathrm{kN}$. W kolejnej fazie obciążania przyrost siły był zmniejszony do $2 \mathrm{kN}$. W tabeli 2 . zestawiono wartość: siłę niszczącą, maksymalny moment skręcający, pomierzone ugięcie, kąt obrotu płaszczyzny bocznej oraz informacje o zaobserwowanym zarysowaniu dla analizowanych belek.

Tabela 2. Wartość siły niszczącej- $\mathrm{P}_{\max }$, moment skręcający $-\mathrm{T}_{\max }$, ugięcie -u, kąt obrotu płaszczyzny bocznej - $\varphi$ i opis zarysowania dla belek B1 i B2

Table 2. Load capacities - $\mathrm{P}_{\max }$, torsional moment $-\mathrm{T}_{\max }$, deflection $-\mathrm{u}$, angle of rotation of the side plane $-\varphi$ and description of the cracks for beams B1 and B2

\begin{tabular}{|c|c|c|c|c|c|c|}
\hline \multicolumn{2}{|c|}{ Element } & $\begin{array}{l}\mathbf{P}_{\max } \\
{[\mathrm{kN}]}\end{array}$ & $\begin{array}{c}\mathbf{T}_{\max } \\
{[\mathrm{kNm}]}\end{array}$ & $\begin{array}{c}\mathbf{u} \\
{[\mathrm{mm}]}\end{array}$ & $\begin{array}{c}\varphi \\
{[\mathrm{deg} / \mathrm{m}]}\end{array}$ & Opis zarysowania \\
\hline \multirow{3}{*}{ B1 } & B1.1 & 126,9 & 38,1 & 14,14 & 1,00 & $\begin{array}{l}\text { pierwsze mikrorysy od zginania - siła } 50 \mathrm{kN} \text {, } \\
\text { pierwsze rysy od ścinania i skręcania na pow. } \\
\text { bocznej belki -siła 70kN, zniszczenie - dominu- } \\
\text { jąca rysa na pow. bocznej szerokości ponad } \\
1,2 \mathrm{~mm} \text {. }\end{array}$ \\
\hline & B 1.2 & 115,5 & 34,7 & 13,52 & 0,89 & $\begin{array}{l}\text { pierwsze mikrorysy od zginania - siła } 50 \mathrm{kN} \text {, } \\
\text { pierwsze rysy od ścinania i skręcania na pow. } \\
\text { bocznej belki -siła } 60 \mathrm{kN} \text {, zniszczenie - dominu- } \\
\text { jąca rysa na pow. bocznej do } 1,1 \mathrm{~mm} \text { oraz od- } \\
\text { dzielenie betonu w strefie ściskanej }\end{array}$ \\
\hline & B 1.3 & 120,4 & 36,1 & 13,48 & 0,99 & $\begin{array}{l}\text { pierwsze mikrorysy od zginania - siła } 55 \mathrm{kN} \text {, } \\
\text { pierwsze rysy od ścinania i skręcania na pow. } \\
\text { bocznej belki -siła } 75 \mathrm{kN} \text {, zniszczenie - rysa } \\
\text { o szerokości ponad } 1,2 \mathrm{~mm}\end{array}$ \\
\hline \multirow{3}{*}{ B2 } & B 2.1 & 93,3 & 28,0 & 10,25 & 0,81 & $\begin{array}{l}\text { pierwsze mikrorysy od zginania - siła } 60 \mathrm{kN} \text {, } \\
\text { pierwsze rysy od ścinania i skręcania na pow. } \\
\text { bocznej belki -siła } 75 \mathrm{kN} \text {, zniszczenie - dominu- } \\
\text { jąca rysa ukośna szerokości ponad } 1,0 \mathrm{~mm}\end{array}$ \\
\hline & B 2.2 & 103,5 & 31,0 & 11,94 & 0,92 & $\begin{array}{l}\text { pierwsze mikrorysy od zginania - siła } 65 \mathrm{kN} \text {, } \\
\text { pierwsze rysy od ścinania i skręcania na pow. } \\
\text { bocznej belki -siła } 75 \mathrm{kN} \text {, zniszczenie - dominu- } \\
\text { jąca rysa ukośna szerokości ponad } 1,0 \mathrm{~mm}\end{array}$ \\
\hline & B 2.3 & 105,2 & 31,6 & 14,36 & 1,01 & $\begin{array}{l}\text { pierwsze mikrorysy od zginania - siła } 65 \mathrm{kN} \text {, } \\
\text { pierwsze rysy od ścinania i skręcania na pow. } \\
\text { bocznej belki -siła } 85 \mathrm{kN} \text {, zniszczenie - dominu- } \\
\text { jąca rysa ukośna szerokości ponad } 1,1 \mathrm{~mm}\end{array}$ \\
\hline
\end{tabular}

\section{Analiza numeryczna}

Analizę numeryczną belek wykonano w programie ATENA 3D - Studio. Do nieliniowej analizy belek żelbetowych wykorzystano trzy modele betonu 
opisujące zależność $\sigma-\varepsilon \mathrm{w}$ złożonym stanie naprężenia. Przyjęto następujące modele betonu:

- model do analizy nieliniowej zaproponowany w Eurokodzie 2 [10],

- model ,cementitious 1”, zaproponowany w programie ATENA bazujący na zaleceniach Model Code 2010 [12] i Model Code 90 [13] - rys. 3.,

- model „cementitious 2”, zmodyfikowany przez użytkownika model betonu „,cementitious”.
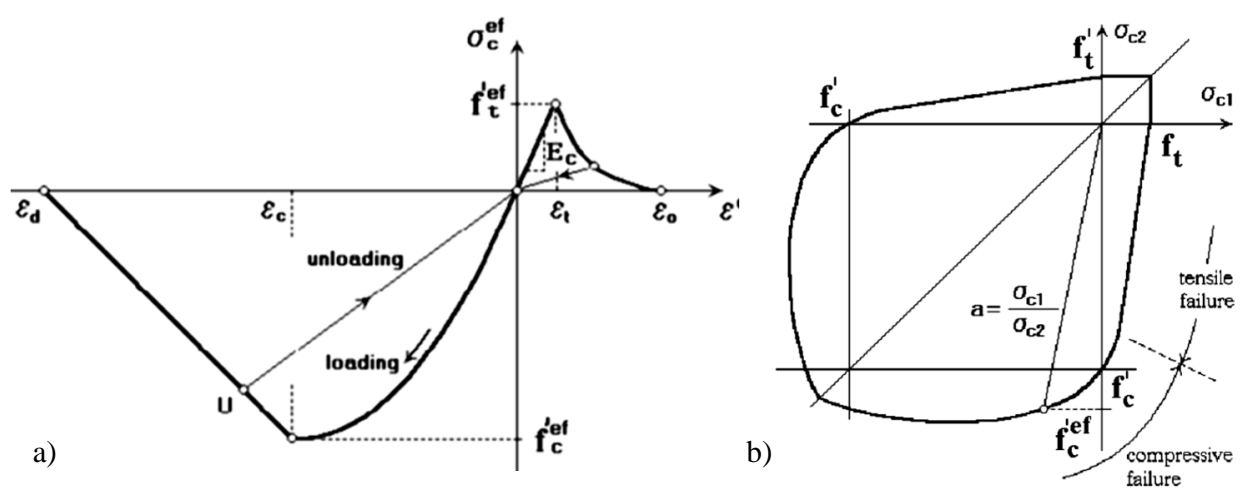

Rys. 3. Związki opisujące modelu „cementitious 1” a) zależność $\sigma-\varepsilon$ w jednoosiowym stanie naprężeń, b) powierzchnia graniczna w dwuosiowym stanie naprężeń [14]

Fig. 3. Relationship for "cementitious" concrete model, a) for uniaxial stress- strain law, b) biaxial stress failure criterion [14]

Związki opisujące zależność $\sigma-\varepsilon \mathrm{w}$ złożonym stanie naprężeń w modelu „,cementitious 2", są analogiczne do zaleceń podanych w modelu ,cementitious 1", ale o parametrach materiałowych ustalonych doświadczalnie lub zmodyfikowanych przez użytkownika. Model ten opisuje zachowanie się betonu w konstrukcjach zbrojonych ze szczególnym uwzględnieniem [14] obniżenia wytrzymałości na ściskanie przy zarysowaniu, usztywniającym wpływie betonu w strefie rozciąganej po zarysowaniu oraz zmianie sztywności na ścinanie po zarysowaniu. Podstawowe parametry opisujące przyjęte modele betonu zestawiono w tabeli 3 .

Zbrojenie zamodelowano wykorzystując model materiałowy „reinforcement", zapewniający przyczepność między betonem i zbrojeniem. Model numeryczny belki B1 przedstawiono na rys. 4.

Analiza numeryczna poprzedzona była oceną wrażliwości wymiarów siatki elementów skończonych. W analizowanych modelach, obciążenie narastało skokowo w 50 krokach. Do rozwiązania nieliniowego układu równań równowagi, podczas symulacji numerycznych wykorzystano metodę długości łuku Crisfielda, jako najbardziej odpowiednią do analizy zarysowanych belek żelbetowych obciążonych siła skupioną [14, 15]. 
Tabela 3. Właściwości materiałowe w modelach betonu

Table 3. Material properties in concrete models

\begin{tabular}{|c|c|c|c|}
\hline & \multicolumn{3}{|c|}{ Model betonu } \\
\hline & EC-2 & $\begin{array}{c}\text { MC - } \\
\text { Cementitious }\end{array}$ & Cementitious 2 \\
\hline $\begin{array}{c}\mathrm{f}_{\mathrm{c}} \text { lub } \mathrm{f}_{\mathrm{c}}^{\text {ef }}-\text { wytrzymałość na ściskanie } \\
\mathrm{w} \text { jednoosiowym stanie naprężeń }[\mathrm{MPa}]\end{array}$ & 64 & 55,6 & 64 \\
\hline $\mathrm{E}_{\mathrm{c}}-$ moduł sprężystości $[\mathrm{MPa}]$ & 38000 & 38088 & 34867 \\
\hline $\begin{array}{l}\mathrm{f}_{\mathrm{t}} \text { lub }_{\mathrm{t}}^{\mathrm{ef}}-\text { wytrzymałość na rozciąganie } \\
\mathrm{w} \text { jednoosiowy stanie naprężeń [MPa] }\end{array}$ & 4,2 & 3,94 & 4,5 \\
\hline v-współczynnik Poissona & 0,2 & 0,2 & 0,15 \\
\hline $\mathrm{G}_{\mathrm{f}}-$ energia pękania $[\mathrm{N} / \mathrm{m}]$ & 105 & 150 & 124 \\
\hline$\rho-$ gęstość betonu $\left[\mathrm{kg} / \mathrm{m}^{3}\right]$ & 2300 & 2300 & 2463 \\
\hline $\begin{array}{c}\varepsilon_{\mathrm{c} 1}-\text { graniczne odkształcenia } \\
\text { sprężysto-plastyczne [\% } \% \text { oo }\end{array}$ & 8,7 & 12,5 & 10,2 \\
\hline
\end{tabular}

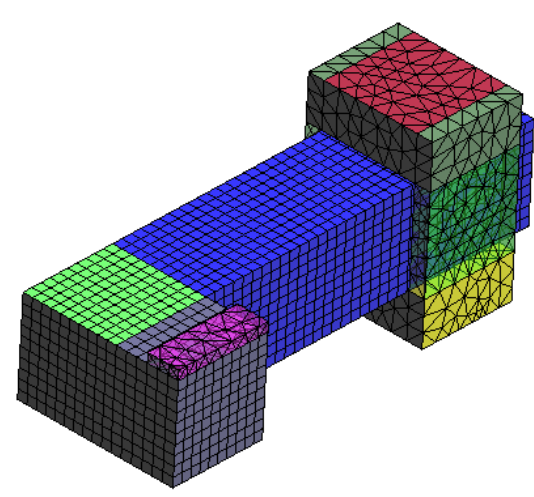

a)

Rys. 4. Model numeryczny belki B1 a) siatka MES, b) model zbrojenia

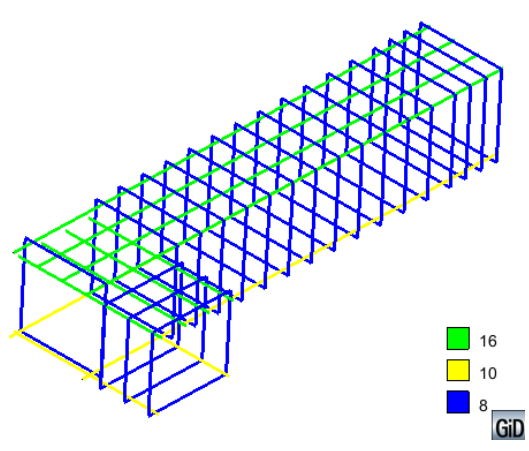

b)

Fig. 4. Numerical model of beam B1 a) MES grid, b) reinforcement model

\section{Analiza wyników badań numerycznych i doświadczalnych}

Na rysunku 5a przedstawiono porównanie nieliniowych zależności obciążenie - przemieszczenie pionowe powierzchni dolnej belek typu B1 otrzymane $\mathrm{w}$ analizach numerycznych i doświadczeniach. Natomiast na rys. 5b przedstawiono porównanie nieliniowych zależności obciążenie - przemieszczenie pionowe powierzchni dolnych dla belek typu B2.

Liniami ciągłymi przedstawiono zależności obciążenie - przemieszczenie uzyskane $\mathrm{z}$ badań doświadczalnych natomiast liniami przerywanym wyniki $\mathrm{z}$ symulacji numerycznych $\mathrm{z}$ uwzględnieniem różnych modeli betonu tj. MES B1, MES B2- model betonu "cementitious 2", MES B1-EC, MES B2-EC - model betonu wg. EC2 [10] oraz MES B1-MC, MES B2-MC - model betonu "cementitious" wg. Model Code [12,13]. 

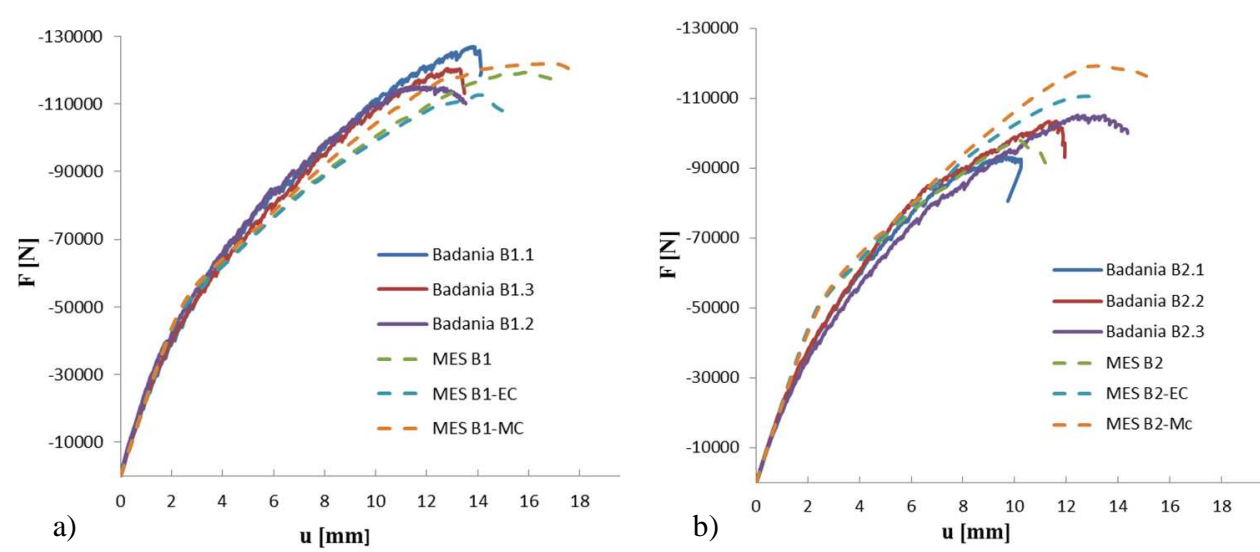

Rys. 5. Zależności obciążenie - przemieszczenie pionowe $\mathrm{z}$ analiz numerycznych i doświadczeniach, a) belki B1, b) belki B2

Fig. 5. The load - vertical displacement relationship of numerical analysis and experiments, a) beams B1, b) beams B2

Model numeryczny belki B1 w obszarze naprężeń sprężystych i po zarysowaniu charakteryzuje się prawie taką samą sztywnością jak belek eksperymentalnych B1.1, B1.2 i B1.3. Największe różnice w wykresie obciążenie - przemieszczenie występują dla obciążeń większych od $75 \mathrm{kN}$ tj. w sytuacji, gdy dominujące są rysy ukośne.

Przedstawiona na rys. 5b zależność obciążenie - przemieszczenie dla belki B2 w obszarze naprężeń sprężystych jest zgodna z wynikami badań doświadczalnych. Największa różnica w wykresie obserwowana jest dla siły od 40 do $70 \mathrm{kN}$. Następnie dla obciążenia ponad $70 \mathrm{kN}$ i zmodyfikowanego modelu betonu (cementitious 2") uzyskano pełną zgodność z wynikami badań doświadczalnych. Najmniejsza zgodność modelu numerycznego z wynikami badań doświadczalnych występuje dla modelu betonu „,cementitious” wg Model Code.

Na rysunkach 6a i 6b przedstawiono sztywność na skręcanie przekroju zarysowanego belek B1 i B2, uzyskaną z symulacji numerycznych dla różnych modeli betonu i badań doświadczalnych.

Numeryczna belka B1 niezależnie od przyjętego modelu betonu charakteryzuje się prawie taką samą sztywnością na skręcanie jak belki eksperymentalne B1.1, B1.2 i B1.3. Gorsze dopasowanie występuje dla belki B2. Jednostkowy kąt skręcenia dla modeli numerycznych i badań doświadczalnych jest zbliżony, wynosi od $0,81 \mathrm{deg} / \mathrm{m}$ do $1,1 \mathrm{deg} / \mathrm{m}$. Natomiast moment skręcający uzyskany dla modelu betonu ,cementitious” wg Model Code jest o $15 \%$ większy od uzyskanego $\mathrm{w}$ badaniach doświadczalnych. Dla zmodyfikowanego modelu betonu (,cementitious 2") sztywność na skręcanie modelu numerycznego jest bardzo bliska sztywności uzyskanej na podstawie badań doświadczalnych belek B2.1, B2.2 i B2.3. 

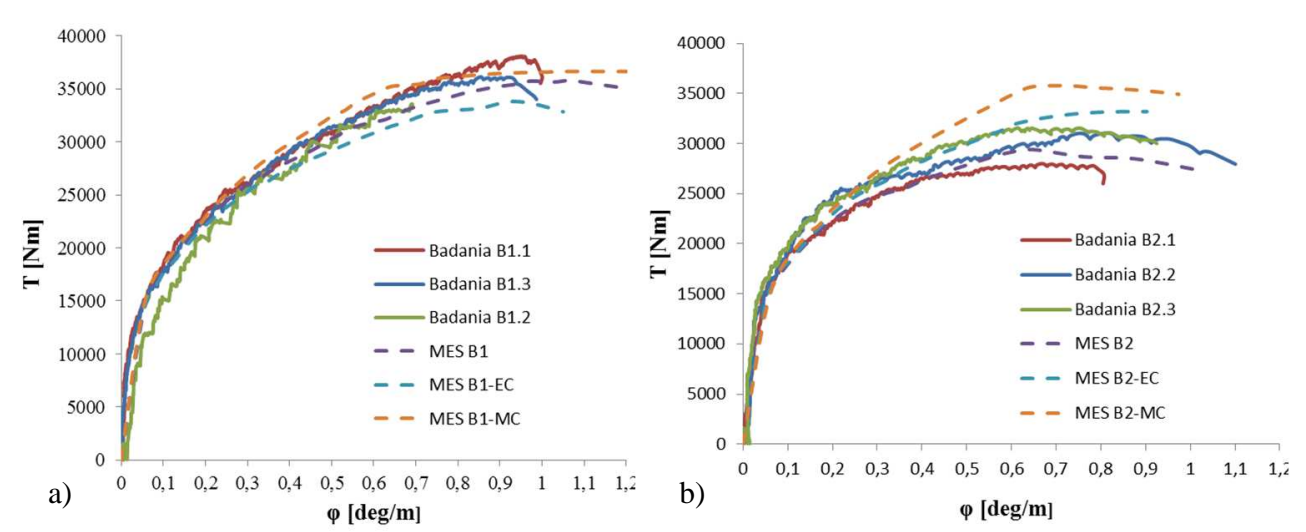

Rys. 6. Sztywności na skręcanie belek w analizach numerycznych i doświadczalnych, a) belki B1, b) belki B2

Fig. 6.Torsional stiffness of beams in numerical and experimental analyzes, a) beams B1, b) beams B2

Na rysunku 7. przedstawiono obraz zarysowania belki B2.3 i numerycznego modelu belki B2 dla wartości obciążeń od 80 do $90 \mathrm{kN}$.

Otrzymane wyniki numeryczne obszarów zarysowanych dla wszystkich analizowanych belek są jakościowo zgodne co do: usytuowania, kierunku i koncentracji rys z wynikami doświadczalnymi.
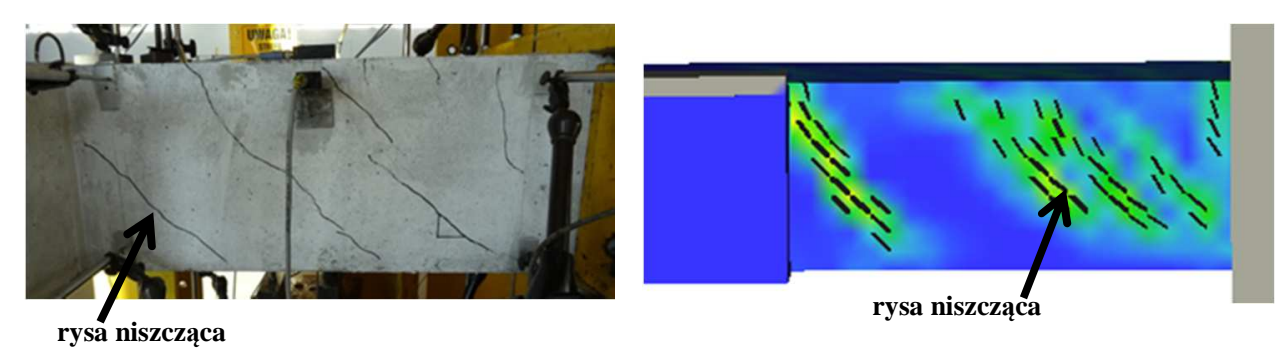

Rys. 7. Zarysowanie belki B2.3 dla obciążenia od 80 do $90 \mathrm{kN}$

Fig. 7. Cracks of beam for load from 80 to $90 \mathrm{kN}$

Również schematy zarysowania uzyskane w rozwiązaniu numerycznym jakościowo dobrze odpowiadają opisom mechanizmu zniszczenia w belkach doświadczalnych. Istnieją jednak pewne niezgodności co do ostatecznego ukształtowania się rysy dominującej. Dla wszystkich belek B2 i dwóch belek B1w badaniach doświadczalnych była to ostania z rys jak pokazano na rys. 7., natomiast dla jednej belek B1 rysa niszcząca ukształtowała się w środku belki. 


\section{Wnioski}

Podsumowując przeprowadzone badania doświadczalne i analizy numeryczne belek o zbrojeniu ukształtowanym na podstawie model ST, różniących się kątem nachylenia krzyżulców ściskanych, tj. $45^{\circ}$ dla belek B1 i 26,6 $6^{\circ}$ dla belek B2, można sfomułować następujące wnioski szczegółowe:

- Średnia nośność belek B1 w badaniach doświadczalnych wynosiła 120,9 kN przy współczynniku zmienności 3,9\%, natomiast dla belek B2 nośność średnia wynosiła 100,7 kN przy współczynnik zmienności 5,1\%.

- Pomierzone ugięcia belek, charakteryzuje większa zmienność. Dla belek B1 wartość średnia ugięcia $\mathrm{z}$ trzech pomiarów wynosi $13,7 \mathrm{~mm}$ przy współczynniku zmienność tylko 2\% natomiast dla belek B2 wartość średnia ugięcia wynosi 12,2 mm przy współczynniku zmienności 13,8\%.

- Wyznaczona na podstawie zależność (1) średnia sztywność na skręcanie belek B1 jest o $12 \%$ większa od średniej sztywność na skręcanie belek B2. Uwzględniając jednak współczynnik zmienności wyników, odpowiednio dla belek B1 3\% i dla belek B2 5\%, nie są to istotne różnice.

- Otrzymane z badań doświadczalnych obrazy zarysowania dla wszystkich analizowanych belek są jakościowo zgodne, co do usytuowania i koncentracji rys. Nie zaobserwowano wpływu sposobu zbrojenia na morfologię zarysowania. Rysy ukośne w badanych belkach były nachylone pod kątem około $37^{\circ}$ do osi podłużnych belek B2 i $41^{\circ}$ do osi belek B1.

- Modele numeryczne belek żelbetowych dla modelu betonu zmodyfikowanego (cementitious 2") mają największą zgodność z wynikami doświadczalnymi w całym zakresie obciążenia belek. Różnice pomiędzy średnim obciążeniem granicznym uzyskanym $\mathrm{w}$ obliczeniach numerycznych a wynikami doświadczalnymi, dla belki B2 wynoszą 3\%, natomiast dla belki B1 $2 \%$.

- Numeryczne modele belek charakteryzują się inną sztywnością na zginanie i skręcanie od belek doświadczalnych. Zaobserwowane ugięcia w modelach numerycznych dla zmodyfikowanego modelu betonu są o około $25 \%$ większe od uzyskanych z badań doświadczalnych.

$\mathrm{Na}$ podstawie przeprowadzonych badań doświadczalnych i analiz można sformułować wnioski ogólne:

- Wybór modelu ST ma wpływ na wartość obciążenia granicznego belek.

- W analizach numerycznych wybór modelu betonu dla elementów pracujących w złożonym stanie naprężeń tj. elementów skręcanych i ścinanych powinien uwzględniać skomplikowany charakter zjawiska i wymaga walidacji doświadczalnej. 


\section{Literatura}

[1] Rausch E., Drillung (Torsion), Shub and Scheren im Stahlbetonbau, VDI Verlag, Dusseldorf, 1953.

[2] Zia P, Mcgee W.D Torsion Design of Prestressed Concrete, PCI Journal, 19 (2): 46-64, 1974.

[3] Hsu T.T.C., Torsion of Structural Concrete, ACI SP-18, 1968.

[4] Ciężak T., Rozwarcie rys w skręcanych elementach żelbetowych, Prace Naukowe Politechniki Lubelskiej 218. Budownictwo 40. Lublin 1990.

[5] Godycki-Ćwirko T., Mechanika betonu, Arkady, Warszawa 1982.

[6] Kamiński M., Pawlak W., Load capacity and stiffness of angular cross section reinforced concreto beams under torsion, Archives of civil and Mechanical Engineering, vol . XI, No.4, p.885-903, 2011.

[7] Budzyński W., Propozycja obliczania szerokości rys ukośnych w elementach żelbetowych jednocześnie skręcanych i ścinanych, Budownictwo i Architektura 2 (2008) 37-64, 2008.

[8] Seruga A, Sokal P. Skręcane elementy z betonu sprężonego w świetle badań doświadczalnych, Czasopismo Techniczne Politechniki Krakowskiej - Budownictwo, zeszyt 21, 2012.

[9] Kosińska A., Nowakowski A.B, Doświadczalne badania żelbetowych elementów poddanych skręcaniu, Wydawnictwo Politechnik Łódzkiej, zeszyt nr 10, Łódź 2001.

[10] PN-EN-1992-1-1: 2008 : Eurokod 2: „Projektowanie konstrukcji z betonu. Część 1-1: Reguły ogólne i reguły dla budynków.

[11] Buda-Ożóg L. Ocena nośności skręcanych i ścinanych belek projektowanych z wykorzystaniem modeli ST, Materiały Budowlane 08/2016, str. 100-102.

[12] Pre-norma Konstrukcji Betonowych, fib Model Code 2010, Kraków 2014.

[13] CEB-FIB Model Code 1990, Bulletin d'information No.195,196.

[14] ATENA Program Documentation, Theory, Praga 2014.

[15] Smarzewski P., Analiza numeryczna niesprężystych belek żelbetowych z betonu wysokiej wytrzymałości o niskim stopniu zbrojenia, Budownictwo i Architektura 4 (2009) 5-30, 2009.

\section{NUMERICAL AND EXPERIMENTAL ANALYSIS OF REINFORCED CONCRETE BEAMS UNDER SHEAR AND TORSION}

\section{S u m m a r y}

The paper presents experimental research and numerical simulations of reinforced concrete beams simultaneously exposed to torsional moment, a bending moment and a shear force. Cantilever concrete beams, made in a real scale with cross section $30 \times 30 \mathrm{~cm}$ were analysed. Reinforcement in the beams was formed on the basis of two different STMs (Strut and Tie Models). For the beam B1, the ST model was a spatial truss, in which the concrete compression diagonal struts, separated by cracks were inclined to the axis of the chords at the angle of $45^{\circ}$. The vertical elements of the truss represent reinforcement in the form of stirrups. The top and bottom chords of the truss represent tension reinforcement and compressed elements. Analogously to the beam B2, 
the ST model was a spatial truss but in the third STM, the diagonal struts were inclined at the angle of $26.6^{\circ}$.

Experimental tests of 6 reinforced concrete beams were performed in the laboratory of The Faculty of Civil and Environmental Engineering and Architecture at Rzeszow University of Technology. In order to assess the load bearing capacity and changes in stiffness of the beams due to bending, torsion and shear, the dependencies: vertical displacement - loading and stiffness of the cross section under torsion were analysed. Numerical simulations of the investigated beams by means of the program ATENA 3D were made. Three models of concrete were used for nonlinear analysis of reinforced concrete beams: the nonlinear concrete model proposed in Eurocode 2, the concrete model "cementitious" proposed in the ATENA program and the concrete model "cementitious 2" with the modification by the user.

Compatibility between the load bearing capacity obtained in numerical simulations and experimental results was observed. On the other hand, the results obtained from numerical analysis showed slightly different flexural stiffness and stiffness under torsion of the beams compared with the experimental results. On the basis of the experimental research and numerical simulations, a significant influence of ST models on the bearing capacity of the beams was demonstrated.

Keywords: torsion, shear, ST models, beams, reinforced concrete, MES

Przestano do redakcji: 01.06.2017r

Przyjęto do druku: 01.09.2017 r 